Key messages

- Around a quarter of people who commit suicide have been in contact with mental health services in the year before death-over 1000 cases annually

- Of these cases, $16 \%$ are psychiatric inpatients and $24 \%$ have been discharged from inpatient care in the previous three months

- Problems of observation caused by ward design and nursing shortages are common in cases of inpatient suicide

- Suicide in former inpatients occurs most commonly in the week after discharge

- Non-compliance with treatment and loss of contact with services are common before suicide

tion. Most of these deaths are by hanging, indicating the need for the removal of structures that make hanging easier such as non-collapsible curtain rails. A quarter of inpatient suicides occur in wards with difficulties in observing patients; this implies that some wards are unsuitable for the care of acutely ill patients. Suicides after discharge from hospital suggest the need for early-in some cases, immediate-follow up after discharge.

Most psychiatric patients who commit suicide are not regarded as being at high immediate risk at their final contact with mental health services. Better suicide prevention may therefore need changes to services for all patients rather than specific initiatives for those known to be at highest risk. A series of recommendations is to be published by the Department of Health ${ }^{10}$; these are based on the above findings and are intended to improve the safety of mental health services as a whole.

We acknowledge the help of district directors of public health; health authority and trust contacts; consultant psychiatrists for completing the questionnaires; Professor Graham Dunn, professor of biostatistics, University of Manchester, for comments on the presentation of the statistical analysis.
Contributors: LA and JS were grant holders and led the design and coordination of the project, data collection, analysis of data, and the writing of the paper. TA and RM contributed to the design of the study and the coordination of data collection, project management, and analysis. $\mathrm{CH}, \mathrm{KM}, \mathrm{SD}, \mathrm{HB}$, and RP contributed to data collection and data management. KK contributed to data management and analysis. All authors approved the final version of the paper. LA is guarantor for the study

Funding: Department of Health; Welsh Office

Competing interests: None declared.

1 Harris EC, Barraclough B. Suicide as an outcome for mental disorders. $\mathrm{Br}$ J Psychiatry 1997;170:205-28

2 Copas JB, Freeman-Browne DL, Robin AA. Danger periods for suicide in patients under treatment. Psychol Med 1971;1:400-4.

3 Goldacre M, Seagroatt V, Hawton K. Suicide after discharge from psychiatric in-patient care. Lancet 1993:342:283-6.

4 Geddes JR, Juszczak E. Period trends in rate of suicide in first 28 days after discharge from psychiatric hospital in Scotland, 1968-92. BMJ 1995:311:357-60

5 Roy A. Risk factors for suicide in psychiatric patients. Arch Gen Psychiatry 1982; 39:1089-95.

6 Henriksson MM, Aro HM, Marttunen MJ, Heikkinen ME, Isometsä ET. et al. Mental disorders and comorbidity in suicide. Am J Psychiatry 1993;150:935-40.

7 Myers DH, Neal CD. Suicide in psychiatric patients. Br J Psychiatry 1978;133:38-44.

8 Department of Health. The care programme approach for people with a mental illness referred to the specialist psychiatric services. London: DoH, 1990. (Circular HC(90)23/LASSL(90)1.)

9 Appleby L, Shaw J, Amos T, McDonnell R, Davies S, Harris C, et al. The national confidential inquiry into suicide and homicide by people with mental illness. Progress report 1997. London: Department of Health, 1997.

10 Appleby L, Shaw J, Amos T, McDonnell R, Kiernan K, Davies S, et al. Safer services. Report of the national confidential inquiry into suicide and homicide by pervices. Report of the national confidential inquiry

people with mental illness. London: HMSO, 1999.
11 Shaw J, Appleby L, Amos T, McDonnell R, Harris C, McCann K, et al. Mental disorder and clinical care in people convicted of homicide national clinical survey. BMJ 1999;318:1240-4.

12 O'Donnell I, Farmer R. The limitations of official suicide statistics. $\mathrm{Br} \mathrm{J}$ Psychiatry 1995;166:458-61.

13 Neeleman J, Wessely S. Changes in classification of suicide in England and Wales: time trends and associations with coroners professional background. Psychol Med 1997;27:467-72.

14 Department of Health. The health of the nation. Strategy for health in England. London: HMSO, 1992.

15 Hawton K, Appleby L, Platt S, Foster T, Cooper J, Malmberg A, et al. The psychological autopsy approach to studying suicide: a review of methodological issues. J Affect Disord 1998;50:269-76.

16 Dixon L, Weiden P, Torres M, Lehman A. Assertive community treatment and medication compliance in the homeless mentally ill. Am J Psychiatry 1997;154:1302-

17 Burns BJ, Santos AB. Assertive community treatment: an update of randomized trials. Psychiatr Serv 1995;46:669-75.

18 Kemp R, Hayward P, Applewhaite G, Everitt B, David A. Compliance therapy in psychotic patients: randomised controlled trial. BMJ 1996; 312:345-9.

19 Home Office. Prison statistics, England and Wales 1997. London: Stationery Office, 1998. (C4017.)

(Accepted 24 March 1999)

\title{
A valuable lesson
}

\section{Always check the $x$ ray film}

In the early 1980s I was a senior house officer in general medicine at Harare Central Hospital, Zimbabwe. Those were years of change in a newly independent country and I had the opportunity to work with a multinational team.

Of the two histopathologists one was a friendly young Briton with a recent MRCPath degree. The other one was also an affable, but most reticent, middle aged man from the former Yugoslavia. He sat bent over his microscope from morning till evening, chain smoking silently and rapidly going through large stacks of slides. While the reports of the Yugoslav were terse those of the Briton were painstakingly detailed and methodical. We learnt to rely on both of them.

Hepatoma is extremely common in Zimbabwe and all too soon I was also inducted into the liver biopsy technique. Ultrasound had not quite made its mark, and on this patient the indications for a liver biopsy were a progressive jaundice, abnormal liver function tests, a positive hepatitis B status, and high $\alpha$-fetoprotein levels. My registrar gave me an almost perfect demonstration and I looked enviously at the sizeable chunk of tissue that he managed to tease out with a Trucut needle. Two days later the senior registrar was taking his round and requested the report of the liver biopsy. Our ward sister promptly brought it over and we all had a look. It comprised the two words "normal spleen" and was signed by the Yugoslav.

For a few seconds the three of us stood as if thunderstruck. The senior registrar was the first to regain his composure. He dashed to the $x$ ray trolley, whipped out the patient's chest $x$ ray film, and put it up for viewing. Yes, the patient had situs inversus.

Till now this was our best kept secret. But since then I have never failed to look at a patient's chest $x$ ray film before performing a procedure.

Rashid N Siddiqui, consultant chest physician, Saudi Arabia 